\title{
Transzmurális szálerősítéses merevítés a nagyméretú MOD kavitások mechanikai ellenálóképességének növelésére - technikai leírás
}

\author{
DR. VOLOM ANDRÁS*, DR. FRÁTER MÁRK**
}

\begin{abstract}
Korunk táplálkozási szokásai és az ezek következtében népbetegséggé vált caries miatt jelentős számban készülnek egyre nagyobb kiterjedésű, mezio-okklúzio-disztális (MOD) kavitásokba kompozíciós tömőanyagból restaurációk. A modern adhezív restaurátumokkal szemben követelmény, hogy állítsák helyre a fog funkcionális egységét, továbbá erősítsék meg azt, kivédve ezzel a későbbi esetleges foganyag-restaurátum komplexumban kialakuló töréseket. Az MOD kavitások kialakítása jelentős mechanikai gyengüléshez vezet, ami döntően a zárólécek elvesztésének, valamint a kavitás dimenzióinak (mélységének) következménye. Bár a mai kompozitok elődeikhez képest jelentős fejlődésen mentek keresztül, az extrém mélységű MOD kavitások ellátására a hagyományos direkt kompozit restaurátumok alkalmassága erősen megkérdőjelezhető. Több vizsgálat szerint az így ellátott fogak mechanikai ellenállóképessége számottevően csökkent.

Cikkünk célja egy olyan új technika bemutatása, ami a kavitás-alakítás során jelentősen meggyengült fogakat képes teherviselőbbé tenni. Az általunk alkalmazott új eljárás, a transzmurális merevítés erős mechanikai kapcsolatot teremt az MOD üreg falai között, így növelve azok ellenállóképességét az okkluzális irányból ható terhelésekkel szemben.
\end{abstract}

Kulcsszavak: MOD kavitás, transzmurális merevítés, szálerősítés, okkluzális terhelés, bruxizmus

\section{Bevezetés}

A konzerváló fogászati munka egyik leggyakrabban végzett kezeléstípusa a jelentősen destruált fogak II. osztályú MOD kavitásainak ellátása direkt vagy indirekt restauratív technikával. Bár az indirekt restauratív megoldás (betét készítése) tartós, jó megoldást jelent az említett esetben, mind a páciens, mind a fogorvos választása többször a direkt technikával, azonnal elkészített tömésekre esik. Ennek hátterében a betétek elkészítéséhez szükséges nagyobb időtartam, többalkalmas fogászati kezelés, valamint a megemelkedett költségek állnak. Az adhezív fogászat robbanásszerű fejlődése és elterjedése óta a MOD kavitásokat leggyakrabban kompozit tömésekkel állítják helyre. Ezen beavatkozások számának további emelkedése várható az amalgám kivezetésének következtében [1].

Manapság a direkt töméseknek a fiziológiás harapási erőnél nagyobb erőket is el kell viselniük. Ennek hátterében számos tényező azonosítható. Napjaink táplálkozási szokásai jelentősen eltérnek az ideálistól. A fogívek bizonyos fokú szükülete és a fogak kisebbnagyobb torlódása szinte általánossá vált. Ennek a folyamatnak a hátterében feltehetően az elégtelen rágás miatt alulfejlett állcsontok és a fogazat méretarányta- lansága áll [2]. Az előbb felvázolt okok is közrejátszhatnak a bruxizmus egyre gyakoribb megjelenésében, ami jelentős túlterhelést jelent a fogazat számára.

Az MOD kavitások az egyik legsérülékenyebb kavitáskonfigurációt képviselik a zárólécek hiánya miatt. A szakirodalomban ismert, hogy a MOD kavitások preparálása jelentősen csökkenti a kezelt fog mechanikai teherviselő képességét [3]. Az így kezelt fogak sérülésének legvalószínübb módja az oldalfalak valamelyikének letörése, ami a fogat érő erők horizontális vektorának számlájára írható. Másképpen megfogalmazva, okkluzális erőterhelés hatására az oldalfalak kihajlanak, a csücsökhegyek eltávolodnak egymástól és ez a fal és a kavitás alapja tájékán horizontális repedést hozhat létre, amely a fal letörését eredményezi [4].

Aggasztó tény, hogy a kavitás mélységének növelésével drasztikusan csökken a MOD kavitások töréssel szembeni ellenállóképessége vitális fogak esetében is, és a ferde rétegzéssel elkészített kompozit tömés nem tudja visszaállítani ezt, vagy megerősíteni a már meggyengült struktúrát [5]. Ennek oka a kompozit törést megállító elégtelen képességében (fracture toughness) keresendő [6], mely nagyobb volumenfaktor esetén egy klinikailag is releváns problémává válik, és a tömés és/ vagy a fog eltörését okozhatja idővel. 
Ismert tény, hogy a nagyméretű kompozit tömések teherviselő képessége növelhető a kavitás belsejébe helyezett polietilén szálerősítő rostokkal [7, 8]. Ugyanakkor a polietilén rostok pontos helyzete kiemelt jelentőségű a restaurált fogak megerősítése szempontjából.

\section{Kezelési koncepció}

Az alább ismertetett technika lényege a nagy kiterjedésü MOD kavitások megerősítése polietilénrostokkal és direkt töméssel. Az alkalmazott technika alapja, hogy a megmaradt két falon kis lyukat fúrva a falakat öszszekötjük egy nyújtó erőkkel szemben nagy ellenállást mutató, ám jól hajlítható ultramagas molekulasúlyú polietilénrosttal (Ribbond Ultra Orthodontic, Ribbond Inc., USA). A technika újdonsága, hogy a polietilénrost a kavitásba történő applikálását követően a polietilénrost feszülés alatt polimerizáljuk, feszülés alatt lett polimerizálva, biztosítva a szemben lévő falak belső sínezését. Az ilyen módon ellátott fogak oldalfalai jóval nehezebben hajlíthatók, ezáltal a fog okkluzális erőkkel szemben mutatott mechanikai ellenállóképessége is jelentősen megnő.

\section{Technikai leírás}

A bemutatott technikát a direkt töméssel még restaurálható, extrém mélységü, de nem gyökérkezelt moláris fogak (mélység $5 \mathrm{~mm}$, falvastagság 2-2,5 mm) esetében javasolt elvégezni. (1. kép)

Az oldalfalak áttörését és a külső felszínén elhelyezkedő külső kazettát mikropreparációs fúróval (MP 53, TwoStriper, Airbrasive Tehcnology inc. USA) hoztuk létre. A bukkális és lingvális falak mesterséges „perforálását” a falak okkluzális kétharmadánál végeztük el. (2. kép)

A kavitás tisztítása és szárítása után az alábbi adhezív protokollt alkalmaztuk: szelektív zománcsavazás után (37\%-os orthofoszforsav 15 másodpercig) (3. kép) lemostuk és megszárítottuk a fogat, majd az adhezív kezelést egy enyhe önsavazó adhezívvel végeztük (G-Premio Bond, GC Europe, Leuven, Belgium) a gyártó utasításait követve. A felvitt réteget 40 másodpercig fotopolimerizáltuk.

A polietilénrostokból álló szalagot mindig be kell mérni és méretre kell vágni a kavitás átmérőjének megfelelően még a rostok előkezelése előtt. (4. kép) A felhasználáshoz előkészítettük a polietilénszálat, amelyet először megbondoztunk, majd a felesleget gyengéd légárammal eltávolítva magas töltöttségú flow kompozittal (G-aenial Universal Flo A3, GC Europe, Leuven, Belgium) impregnáltunk.

A kavitásban először a bukkális áttörést töltöttük fel magas töltöttségű flow kompozittal, majd a flow-n átvezettük az előzetesen bemért hosszúságú polietilénszálat (Ribbond Ultra Orthodontic, Ribbond Inc., USA) és lehajlítottuk a végét a külső kazettába, majd nagyjából 5 másodpercig fotopolimerizáltuk. Ezt követően a rostot áthúztuk a lingvális falon kialakított áttörésen, majd csipesszel, enyhe húzás mellett lehajlítottuk az ott kialakított kazettába és fotopolimerizáltuk. (5. kép) Ezt követően egy körkörös Toffelmire matrica került a fogra, utána a hiányzó meziális és disztális falakat centripetális technikával felépítettük hagyományos kompozittal (G-aenial

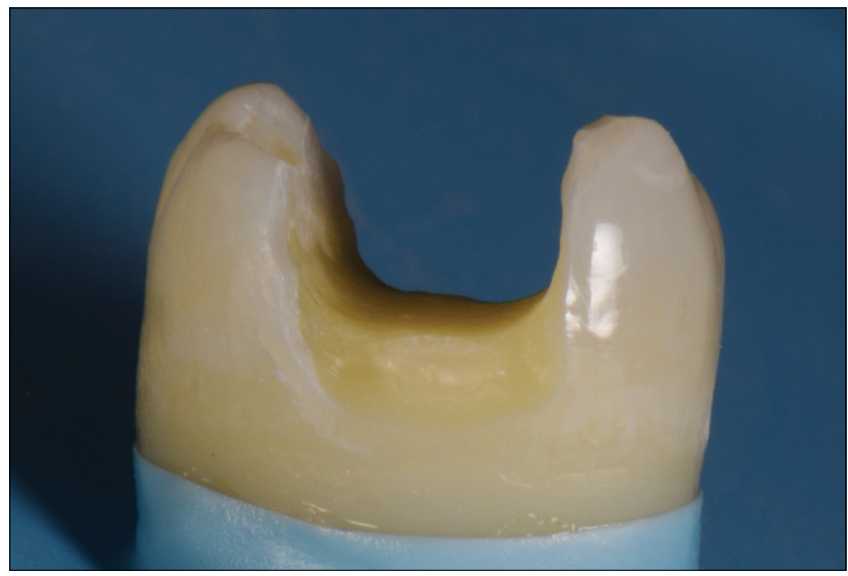

1. kép: Kiindulási szituáció

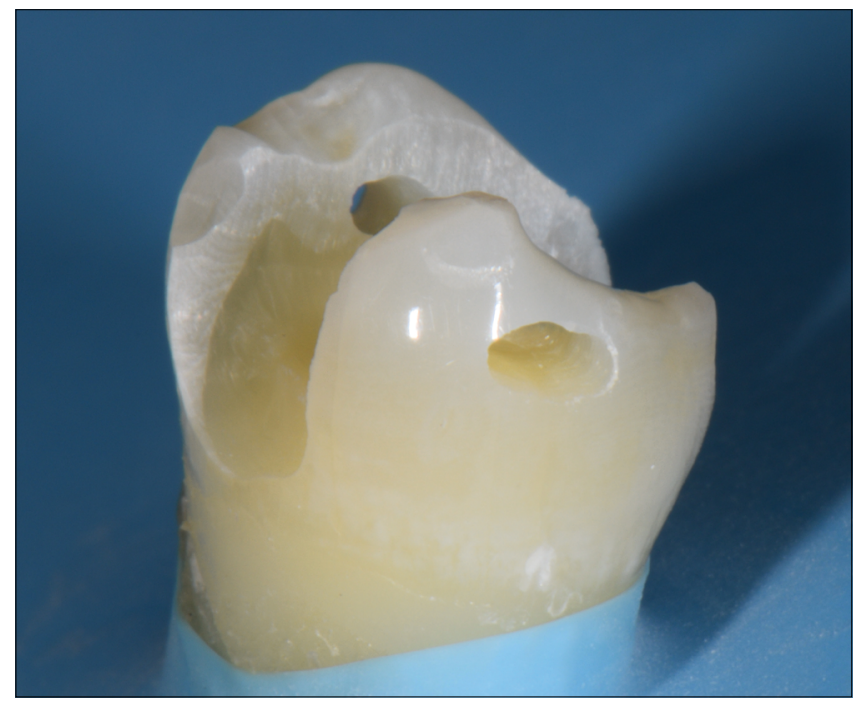

2. kép: A kavitás oldalnézetből

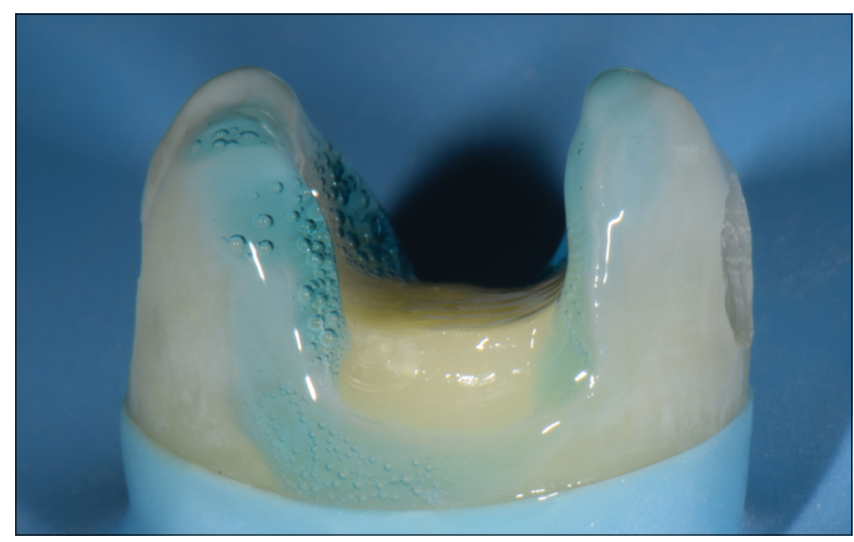

3. kép: A zománcszélek szelektív savazása 


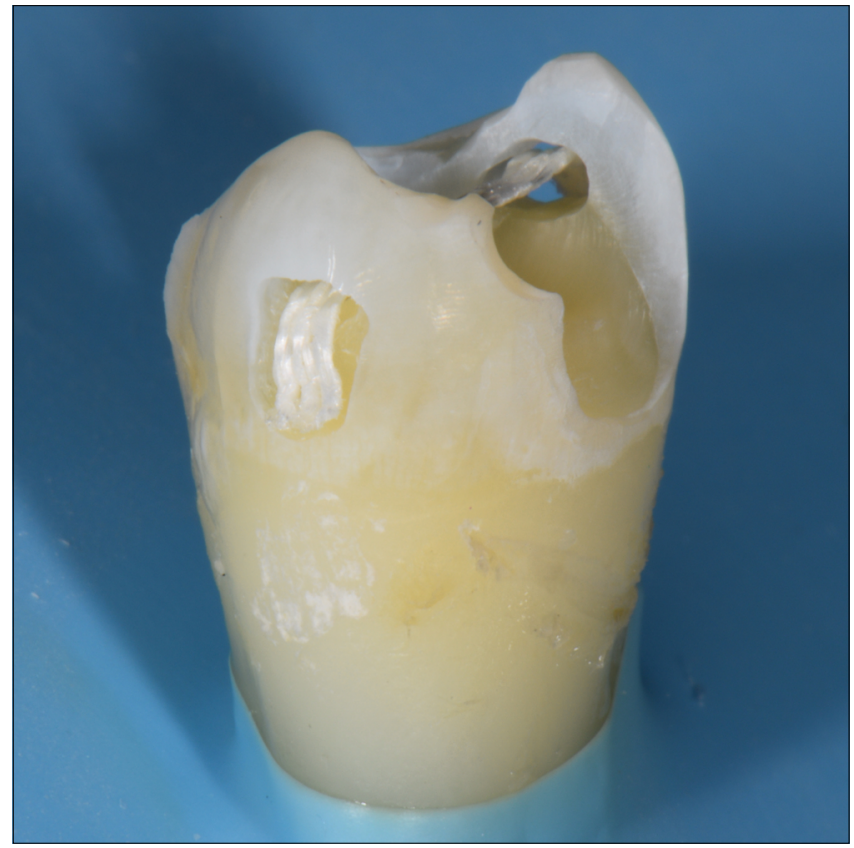

4. kép: A kavitásba bepróbált, ideális hosszúságú Ribbond szalag

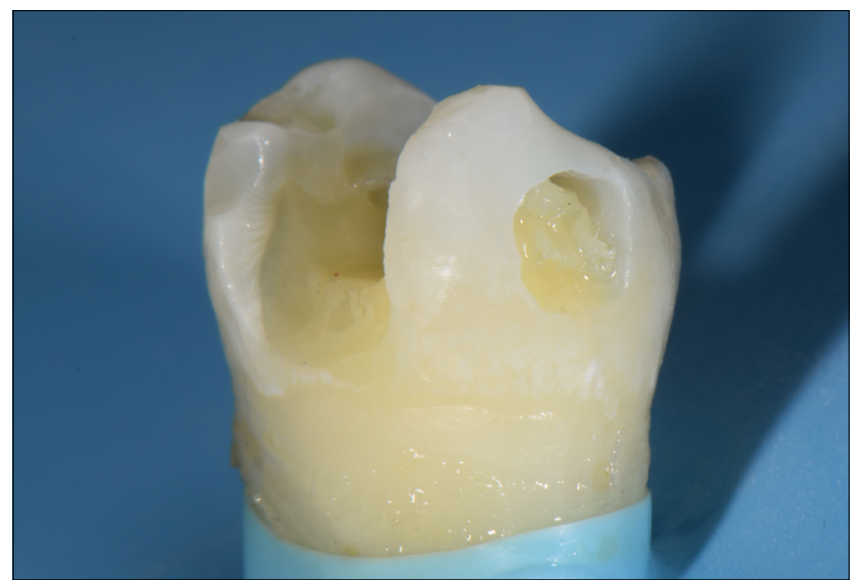

5. kép: A szemben lévő, megmaradt falakat összekötő Ribbond szalag

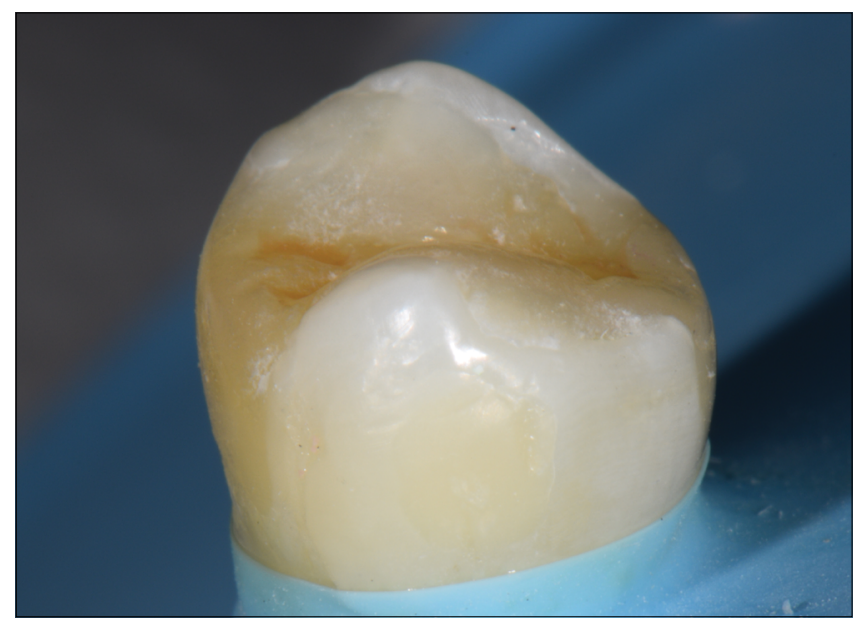

Posterior PJ-E, GC Europe, Leuven, Belgium), ezzel az eredetileg II. osztályú üreget I. osztályúvá alakítva.

A kavitást kompozitból készült rétegzett töméssel láttuk el. A köztes rétegeket 20 másodperig, az utolsó réteget pedig 60 másodpercig fotopolimerizáltuk. (6. és 7. kép)

\section{Megbeszélés}

A minimál invazív fogászat igyekszik a meglévő foganyagból minél többet megtartani, az adhezív restaurátumok pedig igyekeznek helyreállítani a fog mechanikai ellenállását a rágóerőkkel és esetleges traumákkal szemben. Eljárásunk kiválóan illeszkedik ebbe a gondolatiságba, mert alkalmazásával növelni tudjuk a destruált fogak teherviselő képességét. A MOD kavitások belső sínezése polietilénrostok felhasználásával nem új gondolat [9, 10], ugyanakkor a Belli és mtsai. által korábban leírt transzverzális szálerősítéses eljáráshoz képest [10] a transzmurális szálerősítés nem a falakat átvágva - ezáltal jelentős anyagveszteséget okozva rögzül, hanem a falakon áthaladva köti össze azokat. A leírt technika egyedisége abban rejlik, hogy feszülés alatt kapcsolják össze a polietilénrostok a megmaradt bukkális és orális falakat (8. kép), amire eddig, tudomásunk szerint, nem volt példa. Ismert tény, hogy a polietilénrostok jelentős erőknek képesek ellenállni, ha a rostok hossza maximalizálva van és azok „megnyújtva”, feszülés alatt vannak [11]. A kompozit tömések során alkalmazott, a tömésbe ágyazott polietilénrostok további előnye, hogy szinte a pozíciójuktól függetlenül képesek a törési mintázatot kedvező irányba módosítani [12]. Ezt azt jelenti, hogy ha a fog-restaurátum mint adhezív egység törése jön létre, az az esetek döntő többségében a zománc-cement junkció szintjében vagy felette jön létre, így a fog könnyedén újra restaurálható [13]. Ugyanakkor a polietilénrostok fogat megerősítő, azaz a töréssel szembeni ellenállásra gyakorolt hatása erősen függ a rostok restaurátumon belüli pozíciójától [14].

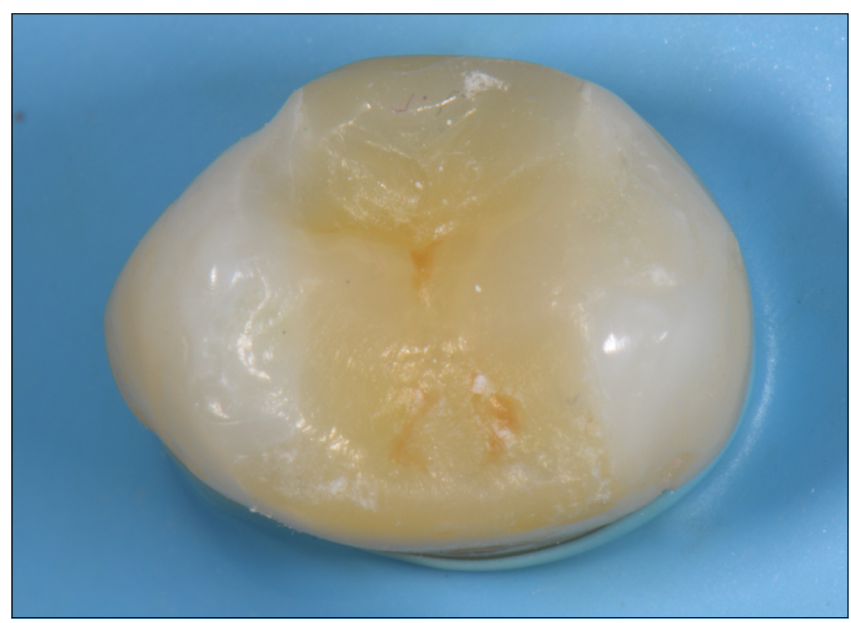

6., 7. kép: Az elkészült direkt szálerősítéses restaurátum 


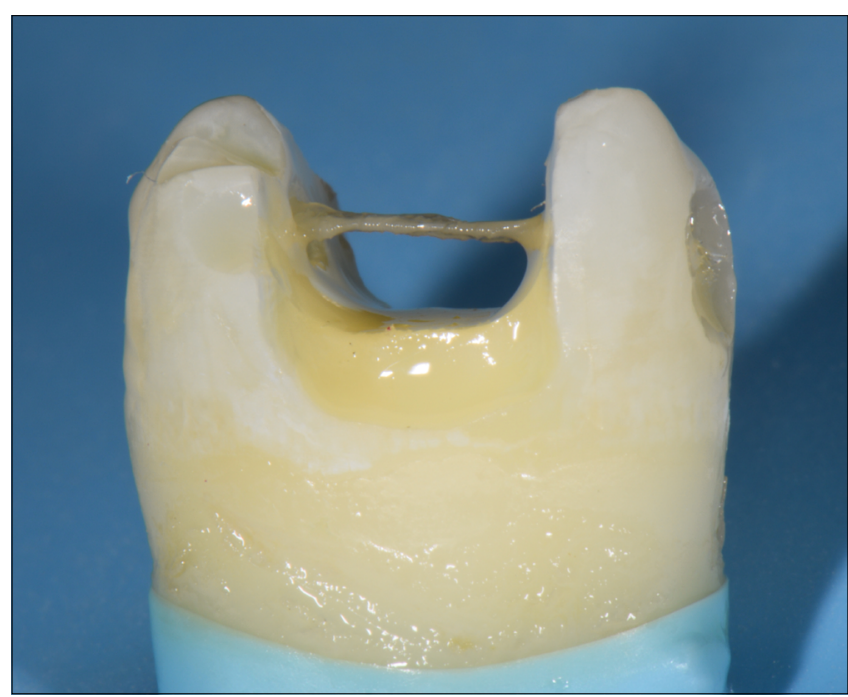

8. kép: A megfeszített polietilén rostok a transzmurális megerősítés elkészítése során

Minden esetben fontos a rostok megfelelő átitatása adhezívvel és flow kompozitba ágyazása, ami növeli a rostok elaszticitási modulusát [15]. A rostok pozicionálása után a töméskészítésre használt hagyományos kompozitot ferde rétegzéssel érdemes használni a kavitásban a napi klinikumban már megszokott módon. Saját tapasztalatunk szerint a transzmurális merevítés alkalmazásával képesek lehetünk mély MOD kavitások esetében megerősíteni a restaurálandó fogat, azaz helyreállítani az egészséges fogra jellemző, töréssel szembeni ellenállást [16].

További vizsgálat tárgya lehet, hogy hogyan befolyásolja az ilyen esetek ellátását és eredményességét, ha hagyományos kompozit helyett bulk-fill kompozittal restauráljuk az üreget a rostok pozicionálása és fixálása után.

\section{Konklúzió}

A bemutatott új technika egy, a napi klinikai praxisban gyakran felmerülő problémára, szituációra kínál relative gyors és tartós direkt restauratív megoldást, melynek lényege a rostok megfelelő pozicionálása és feszülés alatt inkorporálása az egyébként hagyományosnak mondható direkt kompozit restaurátumba.

\section{Irodalom}

1. Mikulás K, Linninger M, Takács E, Kispélyı B, Nagy K, Fejérdy $P$, Hermann P: Paradigm shift in conservative dentistry: the end of the amalgam era. Orv Hetil. 2018 Oct; 159 (42): 1700-1709.

2. Rose JC1, Roblee RD: Origins of dental crowding and malocclusions: an anthropological perspective. Compend Contin Educ Dent. 2009 Jun; 30 (5): 292-300.

3. RocCA GT, KREJCI I: Crown and post-free adhesive restorations for endodontically treated posterior teeth: from direct composite to endocrowns. Eur J Esthet Dent. 2013 Summer; 8 (2): 156-179.

4. Taha NA1, Palamara JE, Messer HH: Fracture strength and fracture patterns of root filled teeth restored with direct resin restorations. J Dent. 2011 Aug; 39 (8): 527-535.

5. Forster A, Braunitzer G, Tóth M, P Szabó B, Fráter M: In Vitro Fracture Resistance of Adhesively Restored Molar Teeth with Different MOD Cavity Dimensions. J Prosthodont. 2019 Jan; 28 (1): e325-e331.

6. Lassila L, Keulemans F, Sailynoja E, Vallittu PK, Garoushi S: Mechanical properties and fracture behavior of flowable fiber reinforced composite restorations. Dent Mater. 2018 Apr; 34 (4): 598-606.

7. Kemaloglu H, Emin Kaval M, Turkun M, Micoogullari Kurt S: Effect of novel restoration techniques on the fracture resistance of teeth treated endodontically: An in vitro study. Dent Mater J. 2015; 34 (5): 618-622.

8. Belli S, Cobankara FK, Eraslan O, Eskitascioglu G, Karbhari V: The effect of fiber insertion on fracture resistance of endodontically treated molars with MOD cavity and reattached fractured lingual cusps. J Biomed Mater Res B Appl Biomater. 2006 Oct; 79 (1): 35-41.

9. Belli S, Erdemir A, Ozcopur M, Eskitascioglu G: The effect of fibre insertion on fracture resistance of root filled molar teeth with MOD preparations restored with composite. Int Endod J. 2005 Feb; 38 (2): 73-80.

10. BeLLI S, ERdemir A, Yildirim C: Reinforcement effect of polyethylene fibre in root-filled teeth: comparison of two restoration techniques. Int Endod J. 2006 Feb; 39 (2): 136-142.

11. Karbhari V, Strassler $\mathrm{H}$ : Effect of fiber architecture on flexura characteristics and fracture of fiber-reinforced dental composites. Dent Mater. 2007 Aug; 23 (8): 960-968.

12. Akman S, Akman M, Eskitascioglu G, Belli S: Influence of several fibre-reinforced composite restoration techniques on cusp movement and fracture strength of molar teeth. Int Endod J. 2011 May; 44 (5): 407-415.

13. Scotti N, Coero Borga Fa, Alovisi M, Rota R, Pasqualini D, BERUTTI $E$ : Is fracture resistance of endodontically treated mandibular molars restored with indirect onlay composite restorations influenced by fibre post insertion? J Dent. 2012 Oct; 40 (10): 814-820.

14. Oskoee PA, Ajami AA, Navimipour EJ, Oskoee SS, Sadjadi J: The effect of three composite fiber insertion techniques on fracture resistance of root-filled teeth. J Endod. 2009 Mar; 35 (3): 413-416.

15. BelLI S, Eskitascioglu G: Biomechanical properties and clinical use of a polyethylene fibre post-core material. International Dentistry South Africa. Vol. 8, No. 3.

16. Sáry T, Garoushi S, Braunitzer G, Alleman D, Volom A, Fráter M: Fracture behaviour of $\mathrm{MOD}$ restorations reinforced by various fibre-reinforced techniques - An in vitro study. J Mech Behav Biomed Mater. 2019 Jul 9;98:348-356. doi: 10.1016/j.jmbbm. 2019.07.006. [Epub ahead of print] PubMed PMID: 31302584. 
András Volom, Márk Fráter

\title{
Transmural fiber reinforcement in order to restore the fracture resistance of large MOD cavities - a technical report
}

Our everyday eating habits and the subsequent caries endemic led to an increase in the number of large MOD cavities restored with direct composite restorations. Today it is a requirement for modern adhesive restorations to not only replace the lost tooth structure but also restore the functional unity of the tooth and increase its fracture resistance, in order to prevent future fractures in the tooth-restoration complex. MOD cavities produce an extremely weakened situation, which is a result of the missing marginal ridges and also highly influenced by the cavity dimensions (especially the depth of the cavity). Although modern composite have undergone major development compared to their previous versions, the usage of conventional composite filling materials to restore large and deep MOD cavities as best practice is highly questionable. According to several studies teeth with the mentioned vulnerable cavities restored with direct composite fillings show reduced fracture resistance.

Our aim with this technical report is to show a technique which is capable of increasing the fracture resistance of teeth that were mechanically destabilized due to extensive loss of sound tooth structure and subsequent cavity preparation. This new method, which is termed transmural reinforcement, is able to form a strong and durable mechanical connection between the remaining cavity walls, leading to increased resistance against occlusal loading.

Keywords: MOD cavity, transmural strengthening, fiber reinforcement, occlusal loading, bruxism

\section{Pályázat \\ Körmöczi-pályadíjra}

\section{0. februárig pályázhatnak a Körmöczi-pályadíjra 35 évnél fiatalabb, a Fogorvosi Szemlében 2019-ben publikáló tagjaink.}

A Magyar Fogorvosok Egyesülete évente pályázaton elnyerhető Körmöczi-pályadíjban részesíti 35 éven aluli tagjainak önálló, színvonalas, tudományos munkán alapuló közleményeit, melyek a megelőző évi Fogorvosi Szemlében jelentek meg. A pályázatok elbírálásánál az eseti bíráló bizottság döntését követően azt az Elnökség egyszerü többségi szavazattal ítéli oda.

A pályadíj három fokozatban elnyerhető, melyek összegei:

\author{
I. fokozat: 200.000 Forint \\ II. fokozat: 150.000 Forint \\ III. fokozat: 100.000 Forint
}

A pályadij megosztva is átadható. A nyertes pályázatok díjainak átadása az MFE konferenciáján, 2020 májusában történik.

Felhívjuk ezért minden 35 év alatti tagunk figyelmét, hogy még van lehetőségük egy idei lapszámban megjelentetni tudományos munkájukat. Használják hát ki a lehetőséget, és nyújtsák be cikküket publikációra, így esélyt szerezvén a pénzdíjra!

A cikkek leadásával kapcsolatosan az MFE weboldalán tájékozódhatnak.

Pályázni csak a 2019-ben a Fogorvosi Szemlében megjelent közleményekkel lehet. Kérjük, a közlemény pdf változatát mellékelje e-mailes pályázatához.

A pályázat beadási határideje: 2020. február 4.

Pályázatukat, kérjük, e-mailben juttassák el az MFE főtitkára, Prof. Dr. Fejérdy Pál részére: fejerdy.pal@dent. semmelweis-univ.hu 